Jurnal Keperawatan Silampari

Volume 4, Nomor 1, Desember 2020

e-ISSN: 2581-1975

p-ISSN: 2597-7482

DOI: https://doi.org/10.31539/jks.v4i1.1627

\title{
TEKNIK REBOZO TERHADAP INTENSITAS NYERI KALA I FASE AKTIF DAN LAMANYA PERSALINAN PADA IBU MULTIGRAVIDA
}

\author{
Yulidian Nurpratiwi ${ }^{1}$, Muhammad $\operatorname{Hadi}^{2}$, Idriani ${ }^{3}$ \\ Institut Medika Drg. Suherman ${ }^{1}$ \\ Universitas Muhammadiyah Jakarta ${ }^{2,3}$ \\ yulidian07nuarif@gmail.com ${ }^{1}$
}

\begin{abstract}
ABSTRAK
Penelitian ini bertujuan untuk mengetahui efektifitas Rebozo Shake The Apples (RSTA) dan Rebozo Sifting While Lying Down (RSWLD) terhadap intensitas nyeri kala I fase aktif dan lamanya persalinan pada ibu multigravida. Metode penelitian ini adalah quasy eksperiment dengan rancangan two group pre dan post design. Hasil penelitian ini menunjukkan bahwa terdapat perbedaan rata-rata intensitas nyeri persalinan kala I fase aktif pada ibu multigravida sebelum dan sesudah pemberian RSTA \& RSWLD ( $\mathrm{p}$ value = 0,007). Sedangkan pada lamanya persalinan tidak terdapat perbedaan yang signifikan ratarata lamanya persalinan antara intervensi teknik RSTA dengan RSWLD ( $p$ value $=0,351$ ) dan pada tingkat efektifitas dari dua teknik Rebozo memiliki varian sama artinya samasama efektif dalam mengalihkan nyeri persalinan kala I fase aktif dan lamanya persalinan ( $\mathrm{p}$ value $=0,118$ ). Simpulan, pemberian RSTA dan RSWLD dapat mengalihkan intensitas nyeri persalinan kala I fase aktif dan lamanya persalinan pada ibu multigravida.
\end{abstract}

Kata Kunci : Intensitas Nyeri, Lamanya persalinan, Multigravida, Teknik Rebozo

\section{ABSTRACT}

This study aims to determine Rebozo Shake The Apples (RSTA) effectiveness and Rebozo Sifting While Lying Down (RSWLD) on the intensity of pain during the first stage of the active phase and the duration of labor in multigravida mothers. This research method is a quasi-experiment with two group pre and post design. This study indicates that there is a difference in the mean intensity of pain in the first stage of active labor in multigravida mothers before and after giving RSTA \& RSWLD ( $p$-value $=0.007)$. Whereas in the length of work, there was no significant difference in the average size of labor between the RSTA and RSWLD technique interventions ( $p$-value $=0.351)$, and the effectiveness of the two Rebozo techniques had the same variant, meaning they were equally effective in diverting labor pain during the active phase and duration of delivery ( -value $=0.118)$. In conclusion, they are giving RSTA, and RSWLD can delay labor pain intensity during the first stage of the active phase and the duration of labor in multigravida mothers.

Keywords: Pain intensity, duration of labor, Multigravida, Rebozo technique 


\section{PENDAHULUAN}

Nyeri persalinan merupakan sebuah pengalaman subjektif tentang sensasi fisik yang terkait dengan kontraksi uterus, dilatasi dan penipisan serviks, serta penurunan janin selama persalinan. Respon fisiologis terhadap nyeri meliputi peningkatan pernapasan, tekanan darah, denyut nadi, diameter pupil, keringat, dan ketegangan pada otot (Wulandari \& Putri, 2018).

Semua ibu hamil pasti akan mengalami rasa nyeri dan merasa khawatir selama proses persalinan. Pada nyeri persalinan dapat ditangani, meskipun nyeri tidak sampai hilang, namun setidaknya dapat mengurangi nyeri persalinan, sehingga dapat memberi rasa kenyamanan terhadap ibu selama proses persalinan. Intervensi penanganan nyeri yang ditentukan tergantung pada pilihan dan kondisi ibu bersalin ataupun perawat maternitas yang menanganinya. Penanganan nyeri persalinan maupun lama persalinan beraneka ragam, baik farmakologi maupun non farmakologi.

Adapun penanganan yang akan diterapkan dalam penelitian ini yaitu terapi non farmakologi, banyak teknik non farmokologi yang sudah dilakukan penelitian sebelumnya seperti massage, acupressure, acupuncture, teknik rileksasi, teknik counterpressure dan teknik yang lainnya, namun peneliti ingin mengembangkan terapi alternatif yang baru dari terapi non farmakologi yang lainnya yaitu teknik dari Mexico. Di Indonesia teknik ini belum pernah dilakukan penelitian pada nyeri dan lamanya persalinan kala I fase aktif yang dilakukan pada saat kontraksi. Dimana teknik rebozo ini berasal dari Amerika Latin. Teknik rebozo adalah sebuah teknik praktis non-invasif yang dilakukan pada wanita berdiri, berbaring atau bertumpu pada tangan dan lututnya. Ini melibatkan gerakan pinggul wanita yang melahirkan yang dikontrol dengan lembut berdampingan dengan menggunakan syal anyaman khusus, dan dilakukan dengan baik oleh bidan atau orang pendukung lainnya (Iversen et al., 2017).

Berdasarkan penelitian Iversen et al., (2017) tentang teknik rebozo untuk mengatasi malposisi janin berjumlah 7 responden, PROM berjumlah 3 responden, penurunan janin berjumlah 3 responden, pereda nyeri berjumlah 1 responden, memperkuat kontraksi 2 responden dan dystocia 1 responden. Teknik rebozo dengan posisi berdiri, tangan dan lutut, serta berbaring bahwa pengalaman para wanita dengan teknik rebozo secara keseluruhan sangat positif, salah satunya meningkatkan rasa kenyamanan selama persalinan. Berdasarkan penelitian Rusniati et al., (2017) bahwa pada ibu bersalin multigravida dengan lamanya persalinan kala I sebanyak 18 responden $(51,4 \%)$ dengan lamanya persalinan 9 jam. Sedangkan lama persalinan pada kala II sebanyak 29 orang $(82,9 \%)$ dengan lamanya persalinan 61-100 menit.

Berdasarkan hasil survey data persalinan normal di Puskemas Cikarang Kabupaten Bekasi pada priode bulan April sampai dengan bulan Desember 2019 sebanyak 144 pasien, sedangkan data bulan Januari 2020 sebanyak 12 pasien. Status obstetri mayoritas pasien multigravida dengan menimbangkan karakteristik masyarakat diwilayah Cikarang mayoritas menengah kebawah dan belum siap dengan era digital, yang mana karakteristik masyarakat tersebut dalam mengalihkan nyeri persalinan masih menggunakan hal-hal yang tradisional, mudah, praktis dan murah seperti teknik rileksasi. Pentingnya peranan perawat dalam meningkatkan kenyamanan terhadap intensitas nyeri persalinan dengan memodifikasi teknik terbaru yaitu teknik RSTA dan RSWLD pada saat kontraksi persalinan kala I fase aktif. Penelitian tentang nyeri dan lama persalinan sudah banyak 
dilakukan, namun pada penelitian ini lebih difokuskan pada teknik rebozo (RSTA) dan RSWLD), selain itu penelitian ini belum pernah dilakukan pada penelitian sebelumnya.

\section{METODE PENELITIAN}

Desain penelitian ini quasy eksperiment, dengan jenis rancangan two group pre dan post design. Sampel berjumlah 34 responden terdiri 17 responden pada kelompok intervensi teknik RSTA dan 17 responden pada kelompok intervensi teknik RSWLD. Teknik pengambilan sampel accidental sampling. Dengan instrumen lembar kuisioner karakteristik responden dan lembar observasi intensitas nyeri persalinan kala I fase aktif dan lamanya persalinan yaitu dengan NRS (Numeric Rating Scale).

Adapun prosedur pengambilan data peneliti mengajukan permohonan tertulis kepada Ketua Program Studi Magister Ilmu Keperawatan Universitas Muhamidyah Jakarta untuk meminta permohonan izin melakukan penelitian di Pelayanan Kesehatan wilayah Kecamatan Cikarang Kabupaten Bekasi yang akan ditujukan kepada Kesbangpol Kabupaten Bekasi dengan tembusan ke Puskesmas.

Setelah disetujui penelitian, peneliti melakukan kontrak program terkait tujuan dilakukan penelitian dan persamaan persepsi tentang lembar kuisioner dan lembar observasi yang harus dilakukan oleh asisten peneliti (bidan atau perawat). Asisten peneliti dalam penelitian ini adalah yang sudah terlatih dalam teknik rebozo sifting while lying down dan rebozo shake the apples. Kemudian setelah peneliti mendapat calon responden, jelaskan tentang maksud dan tujuan dan prosedur pelaksanaan, apabila calon responden bersedia, maka calon responden wajib mengisi lembar persetujuan (informed consent). Observasi pengukuran intensitas nyeri dilakukan pada kala I fase aktif pada ibu multigravida dimana observasi yang akan dilakukan 4 kali pengukuran pada saat kontraksi setiap 30 menit.

Lamanya dilakukan tindakan 5-10 menit. Observasi intensitas nyeri persalinan dan lamanya persalian pada intervensi teknik RSTA disebut kelompok A dan pada teknik RSWLD disebut kelompok B. Pengukuran intensitas nyeri persalinan Pre adalah tanpa intervensi (pengukuran A1 dan B1), dan post adalah dilakukan intervensi (pengukuran A2, A3, A4 dan B2, B3, B4). Sedangkan pengukuran lamanya persalinan diukur setelah proses persalinan selesai.

Pengolahan data dengan editing, coding, entry dan clearing, sedangkan analisis data pada karakteristik responden dan observasi intensitas nyeri persalinan dengan NRS dan lamanya persalinan yang disajikan dalam bentuk tabel distribusi frekuensi dan persentasi. Analisis data dilakukan untuk melihat data frekuensi dan persentase karakteristik responden, intensitas nyeri dan lamanya persalinan dengan analisis univariat, untuk melihat perbedaan pre dan post intensitas nyeri persalinan dan lamanya persalinan dari 2 kelompok intervensi rebozo menggunakan analisis bivariat dengan uji $t$-test berpasangan dan melihat hasil efektifitas dari 2 kelompok intervensi teknik rebozo yang dilakukan pengukuran secara berulang menggunakan analisis multivariat dengan uji general linear model. 


\section{HASIL PENELITIAN}

\section{Univariat}

Tabel. 1

Distribusi Frekuensi Rata-Rata

Karakteristik Responden

\begin{tabular}{|c|c|c|c|c|c|c|}
\hline \multirow{2}{*}{\multicolumn{2}{|c|}{ Karakteristik }} & \multicolumn{2}{|c|}{$R S T A$} & \multicolumn{2}{|c|}{$R S W L D$} & \multirow{2}{*}{$p$ Value } \\
\hline & & (f) & $(\%)$ & (f) & $(\%)$ & \\
\hline \multirow[t]{2}{*}{ Usia } & $<20,>35$ tahun & 6 & 35,3 & 5 & 29,4 & \multirow[b]{2}{*}{0,484} \\
\hline & 20-35 tahun & 11 & 64,7 & 12 & 70,6 & \\
\hline \multirow[t]{2}{*}{ Agama } & Muslim & 16 & 94,1 & 16 & 94,1 & \multirow{2}{*}{1,000} \\
\hline & Non Muslim & 1 & 5,9 & 1 & 5,9 & \\
\hline \multirow{4}{*}{ Pendidikan } & SD & 1 & 5,9 & 3 & 17,6 & \multirow{4}{*}{0,238} \\
\hline & SMP & 5 & 29,4 & 4 & 23,5 & \\
\hline & SMA & 10 & 58,8 & 9 & 52,9 & \\
\hline & $\mathrm{PT}$ & 1 & 5,9 & 1 & 5,9 & \\
\hline \multirow[t]{2}{*}{ Pekerjaan } & Tidak Bekerja & 16 & 94,1 & 16 & 94,1 & \multirow{2}{*}{1,000} \\
\hline & Bekerja & 1 & 5,9 & 1 & 5,9 & \\
\hline
\end{tabular}

Berdasarkan tabel 1 menunjukkan bahwa dari 34 responden rata-rata pada karakteristik usia terbesar yaitu pada kelompok intervensi teknik RSWLD $12(70,6 \%)$ responden dengan rentang usia 20-35 tahun, sedangkan agama yang terbanyak adalah agama islam, baik pada RSTA maupun RSWLD dengan sama-sama memiliki nilai rata-rata sebesar 16 responden $(94,1 \%)$, tingkat pendidikan yang terbanyak pada intervensi teknik RSTA 10 responden $(58,8 \%)$ berpendidikan SMA, sedangkan status pekerjaan yang terbanyak tidak bekerja, baik pada intervensi RSTA maupun RSWLD dengan sama-sama memiliki nilai rata-rata sebesar 16 responden $(94,1 \%)$. Dari tabel tersebut juga diketahui bahwa pada masing-masing variabel memiliki $p$ value $>0,05$, sehingga dapat dikatakan bahwa tidak ada perbedaan antara kelompok intervensi RSTA dengan RSWLD.

Tabel. 2

Distribusi Frekuensi Rata-Rata Nyeri dan Lamanya Persalinan

\begin{tabular}{|c|c|c|c|c|c|c|c|}
\hline & Variabel & & $\mathrm{N}$ & Mean & SD & Min-max & $p$ value \\
\hline \multirow{8}{*}{ Nyeri } & \multirow[t]{4}{*}{$R S T A$} & A1 & \multirow{4}{*}{17} & 8,59 & 0,939 & $7-10$ & 0,052 \\
\hline & & A2 & & 7,94 & 1,029 & $6-10$ & 0,193 \\
\hline & & A3 & & 7,41 & 0,939 & $6-9$ & 0,052 \\
\hline & & A4 & & 7,47 & 1,068 & $6-10$ & 0,064 \\
\hline & \multirow[t]{4}{*}{$R S W L D$} & B1 & 17 & 8,59 & 0,939 & $7-10$ & 0,052 \\
\hline & & B2 & & 7,82 & 1,237 & $6-10$ & 0,112 \\
\hline & & B3 & & 7,76 & 1,033 & $6-10$ & 0,068 \\
\hline & & B4 & & 7,41 & 0,939 & $6-9$ & 0,052 \\
\hline \multirow{2}{*}{$\begin{array}{l}\text { Lamanya } \\
\text { persalinan }\end{array}$} & $R S T A$ & & \multirow{2}{*}{17} & 139,00 & 43,255 & $80-230$ & \multirow{2}{*}{0,137} \\
\hline & $R S W L D$ & & & 154,53 & 46,322 & $100-258$ & \\
\hline
\end{tabular}


Berdasarkan tabel 2 menunjukkan bahwa rata-rata intensitas nyeri persalinan kala I fase aktif pada teknik RSTA pengukuran 1 memiliki rata-rata sebesar 8.59, pengukuran 2 sebesar 7.94, pengukuran 3 sebesar 7.41 dan pengukuran 4 sebesar 7.47, sehingga dari 4 pengukuran tersebut nilai rata-rata yang paling tinggi yaitu pada pengukuran pertama sebesar 8,59, sedangkan yang terendah pada pengukuran ketiga sebesar 7,41. Sedangkan pada teknik RSWLD pengukuran 1 memiliki rata-rata sebesar 8,59, pengukuran 2 sebesar 7,82, pengukuran 3 sebesar 7.76 dan pengukuran 4 sebesar 7,41. Sehingga dari 4 pengukuran tersebut nilai rata-rata yang paling tinggi yaitu pada pengukuran yang pertama sebesar 8,59, dan yang terendah pada pengukuran keempat sebesar 7,41. Sedangkan nilai rata-rata lamanya persalinan dari pengukuran 1 sampai dengan pengukuran ke 4 yang paling lama persalinannya pada intervensi kelompok teknik RSWLD yaitu sebesar 154 menit, sedangkan lama persalinan yang paling singkat pada teknik RSTA adalah 139 menit.

\section{Bivariat}

Tabel. 3

Perbedaan Rata-Rata Sebelum dan Sesudah Pemberian Intervensi pada Teknik RSTA dan RSWLD terhadap Intensitas Nyeri Kala I Fase Aktif dan Lamanya Persalinan pada Ibu Multigravida

\begin{tabular}{|c|c|c|c|c|c|}
\hline Variabel & & $\mathrm{N}$ & Mean & SD & $p$ value \\
\hline $\begin{array}{l}\text { Intensitas nyeri } \\
R S T A\end{array}$ & $\begin{array}{l}\text { Pre } \\
\text { Post }\end{array}$ & 17 & $\begin{array}{l}8,59 \\
7,94 \\
\end{array}$ & $\begin{array}{l}0,939 \\
1,029 \\
\end{array}$ & 0,007 \\
\hline$R S W L D$ & $\begin{array}{l}\text { Pre } \\
\text { Post }\end{array}$ & 17 & $\begin{array}{l}8,59 \\
7,82\end{array}$ & $\begin{array}{l}0,939 \\
1,237\end{array}$ & 0,000 \\
\hline Lamanya persalinan & $\begin{array}{c}R S W L D \\
R S T A\end{array}$ & $\begin{array}{l}17 \\
17\end{array}$ & $\begin{array}{l}154.53 \\
139.00\end{array}$ & $\begin{array}{l}46.322 \\
43.255\end{array}$ & 0,351 \\
\hline
\end{tabular}

Berdasarkan tabel 3 menunjukkan bahwa pengukuran nilai rata-rata intensitas nyeri persalinan pada pre intervensi RSTA sebesar 8,59 dengan standar deviasi 0,939. Pengukuran nilai rata-rata intensitas nyeri persalinan pada post intervensi RSTA sebesar 7,94 dengan standar deviasi 1,029. Hasil analisis dependent sample t test terlihat nilai signifikansi 2 arah (2-tailed) sebesar 0,007 < 0,05, yang berarti terdapat perbedaan signifikan antara pre dan post pada intervensi teknik rebozo shake the apples. Hasil analisis dependent sample t-test terlihat nilai signifikans 2 arah (2-tailed) sebesar 0,000<0,05, yang berarti terdapat perbedaan signifikan antara pre dan post pada intervensi teknik rebozo sifting while lying down.

Berdasarkan tabel 3 menunjukkan bahwa kedua intervensi mempunyai masingmasing 17 sampel. Dari hasil analisis lamanya persalinan pada intervensi teknik RSWLD lebih tinggi dari pada teknik RSTA dengan nilai rata-rata 154 menit dengan 139 menit. Hasil analisis dependent sample t-test terlihat nilai signifikans 2 arah (2-tailed) sebesar $0,351>0,05$ artinya tidak terdapat perbedaan yang signifikan rata-rata lamanya persalinan antara intervensi teknik RSWLD dengan teknik RSTA.I 


\section{Multivariat}

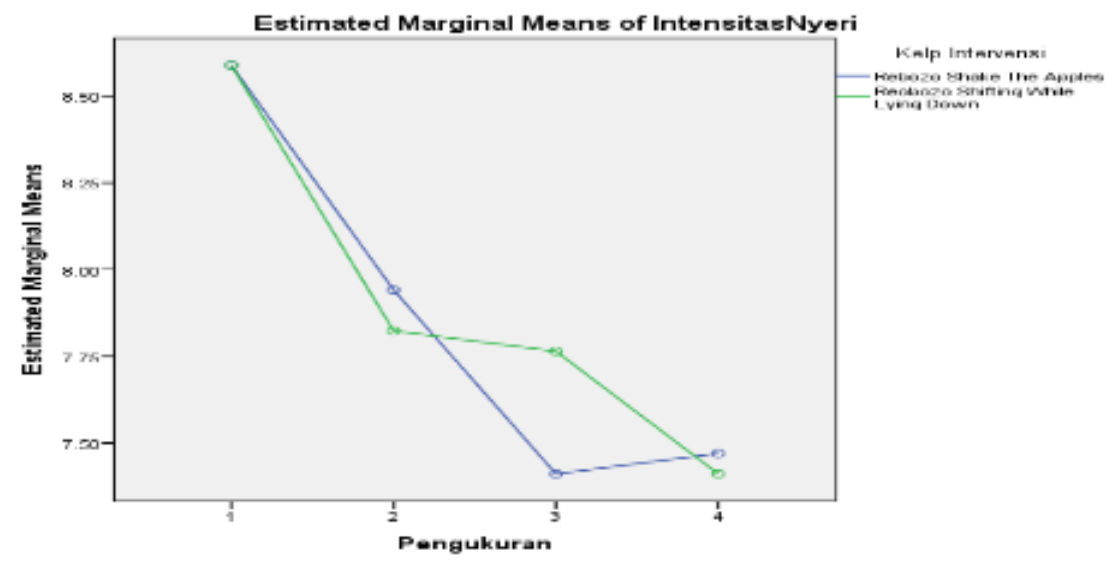

Gambar. 1

Grafik Efektifitas Teknik RSTA dengan Teknik RSWLD terhadap Intensitas Nyeri Persalinan Kala I Fase Aktif pada Ibu Multigravida

Berdasarkan gambar 1 menunjukkan bahwa ada interaksi yang signifikan antara pengukuran intensitas nyeri persalinan dengan teknik rebozo. Sehingga dapat dilihat bahwa teknik RSTA lebih efektif pada pengukuran intensitas nyeri yang ke 3 dibandingkan teknik RSWLD. Tetapi pada pengukuran intensitas nyeri yang ke 4 lebih efektif pada teknik rebozo sifting while lying down. Maka dapat disimpulkan bahwa perbedaan pengukuran intensitas nyeri persalinan terhadap teknik rebozo shake the apples dengan teknik rebozo sifting while lying down tidak terlalu besar, jadi dari dua kelompok intervensi sama-sama efektif dalam mengalihkan nyeri persalinan kala I fase aktif pada ibu multigravida.

\section{PEMBAHASAN}

\section{Karakteristik Responden}

Berdasarkan hasil analisis penelitian ini yang didapatkan bahwa frekuensi rata-rata terbesar usia ibu multigravida pada persalinan kala I fase aktif didapatkan usia dengan rentang 20-35 tahun. Pada penelitian ini responden berusia 20-35 tahun yang merupakan rentang usia yang paling baik untuk melahirkan dan usia yang paling produktif, aman, sehat dan pola berfikirnya sudah matang sehingga tidak menutup kemungkinan pada usia ini dapat mengendalikan nyeri persalinan dan lamanya persalinan dengan baik.

Menurut Nursalam bahwa semakin cukup umur, maka tingkat kematangan dan kekuatan seseorang akan lebih matang dalam berfikir dan bekerja, sedangkan menurut Hurlock usia 20-35 tahun dikatakan masa dewasa dan reproduksi, dimana pada masa ini secara emosional diharapkan mampu menghadapi masalah-masalah selama persalinan.

Penelitian ini tidak sejalan dengan penelitian Maryuni (2020) menunjukkan bahwa tidak terdapat hubungan antara usia dengan nyeri persalinan, hal ini disebabkan karena nyeri persalinan bersifat subyektif dan dipengaruhi oleh banyak faktor lainnya. 
Hasil penelitian ini menunjukkan bahwa rata-rata frekuensi agama pada intervensi teknik rebozo shake the apples maupun rebozo sifting while lying down sebagian besar beragama Islam.

Pada penelitian ini terkait dengan aspek spiritual individu, dimana spiritual merupakan keyakinan dalam hubungannya dengan Yang Maha Kuasa atau percaya pada Allah. Dimana aspek spiritual berhubungan dengan sesuatu yang tidak diketahui atau ketidakpastian dalam kehidupan, menemukan arti dan tujuan hidup, menyadari kemampuan untuk menggunakan sumber dan kekuatan dalam diri sendiri serta mempunyai perasaan keterikatan dengan diri sendiri dan dengan Yang Maha Esa. Pada dasarnya keyakinan seseorang berbeda-beda meskipun agamanya sama, hal ini tergantung dari tingkat keyakinan seseorang terhadap agama yang dimilikinya. Maka kemungkinan keyakinan seseorang dapat mempengaruhi intensitas nyeri persalinan dan lamanya persalinan, sehingga nyeri persalinan maupun lamanya persalinan dapat dialihkan dengan membaca doa atau berzikir atau mendengar murrotal, sehingga responden lebih nyaman dan rileks dalam melewati proses persalinan.

Dalam penelitian ini menunjukkan rata-rata frekuensi terbesar memiliki tingkat pendidikan SMA yaitu 58,8\% pada intervensi teknik rebozo shake the apples dan 52,9\% pada teknik rebozo sifting while lying down dengan $p$ value $0,238>0,05$ artinya pendidikan pada teknik rebozo shake the apples dan rebozo sifting while lying down memiliki varian yang sama. Secara umum tingkat pendidikan mempengaruhi kemampuan individu dalam menerima dan memahami informasi terkait kondisi dan lingkungannya, sehingga dapat mempengaruhi cara pandang dan koping individu dalam menyelesaikan masalah yang dihadapinya. Hal ini menunjukkan bahwa latar belakang pendidikan SMA sudah mampu memahami dan mengetahui tentang proses persalinan, sehingga dengan pengetahuan yang ia miliki sudah mampu mengantisipasi nyeri persalinan, dan didukung dengan pengalaman sebelumnya yang dimilikinya.

Sejalan dengan penelitian Puspitasari \& Astuti (2017) bahwa freakuensi yang terbesar berpendidikan SMA, hal ini menunjukkan masih ada responden yang berpendidikan menengah sehingga sudah mampu mengetahui pengetahuan terkait persalinan dan teknik yang digunakan untuk mengurangi nyeri persalinan.

Dalam penelitian ini menunjukkan rata-rata frekuensi terbesar pada status pekerjaan yaitu $94,1 \%$ ibu yang tidak bekerja baik pada intervensi teknik rebozo shake the apples maupun rebozo sifting while lying down dengan $p$ value 1,000, artinya status pekerjaan pada teknik rebozo shake the apples dan rebozo sifting while lying down memiliki varian yang sama. Status tidak bekerja disini adalah ibu rumah tangga yang tidak memiliki aktivitas diluar rumah dan tidak menghasilkan ekonomi. Maka status pekerjaan resiko mempengaruhi terhadap status ekonomi, dimana kondisi ekonomi yang kurang seperti biaya lahiran dan persiapan persalinan sering kali menimbulkan kecemasan tersendiri dalam menghadapi persalinan, sehingga kecemasan yang berlebihan sangat mempengaruhi peningkatan nyeri persalinan dan efek dari kecemasan dalam persalinan dapat mengakibatkan kadar katekolamin yang berlebihan, sehingga menyebabkan turunnya aliran darah ke rahim, turunnya kontraksi rahim,tu runnya aliran darah ke plasenta, turunnya oksigen yang tersedia untuk janin serta dapat meningkatkan lamanya persalinan. 
Menurut encyclopedia of children's health, ibu bekerja adalah seorang ibu yang bekerja di luar rumah untuk mendapatkan penghasilan di samping membesarkan dan mengurus anak di rumah. Status pekerjaan mempengaruhi status ekonomi keluarga. Semakin baik status ekonominya, maka semakin baik dalam memfasilitasi biaya kehidupannya, begitu juga sebaliknya. Sejalan dengan penelitian Purnama \& Dewiani (2019) bahwa nilai frekuensi terbesar pada ibu yang tidak bekerja, sehingga dapat mempengaruhi status ekonomi sering mempengaruhi keadaan nyeri persalinan.

\section{Nyeri Persalinan}

Dalam penelitian ini juga menunjukkan rata-rata frekuensi dari pengukuran pertama intensitas nyeri persalinan kala I fase aktif sampai dengan pengukuran keempat pada teknik rebozo shake the apples dan rebozo sifting while lying down yang terbesar yaitu pada pengukuran pertama yang memiliki rata-rata 8,59 responden dan yang terendah pada pengukuran 3 pada Rebozo Shake The Apples dan pengukuran 4 pada rebozo sifting while lying down yang memiliki nilai rata-rata 7,41 responden.

Pengukuran pertama pada intensitas nyeri persalinan dari 2 teknik rebozo merupakan pengukuran sebelum dilakukan intervensi teknik rebozo shake the apples maupun rebozo sifting while lying down, dimana kondisi ini persepsi nyeri persalinan masih tinggi karena belum di stimulasi dengan teknik rebozo yang diberikan. Sehingga nyeri persalinan masih dalam skala nyeri berat terkontrol dan tidak terkontrol. Pada pengukuran ketiga intensitas nyeri persalinan pada teknik rebozo shake the apples dan pengukuran keempat pada teknik rebozo sifting while lying down merupakan pengukuran nyeri persalinan yang sudah dilakukan intervensi teknik rebozo shake the apples maupun rebozo sifting while lying down. Hal ini menunjukkan bahwa dengan teknik rebozo terdapat respon nyeri berat tidak terkontrol menjadi nyeri berat terkontrol bahkan sampai ke nyeri sedang. Namun tidak menutup kemungkinan selain teknik rebozo, berkurangnya intensitas nyeri juga dapat dipengaruhi oleh faktor yang lain seperti paritas, karena paritas multigravida sudah memiliki pengalaman bersalin, apabila pengalaman sebelumnya nya baik dalam melewati proses persalinan, maka tidak menutup kemungkinan pasien mampu menjaga koping individunya dalam mengatasi nyeri persalinan.

Sejalan dengan pernyataan penelitian Supliyani (2017) menunjukkan bahwa 57\% responden multigravida telah memiliki pengalaman melahirkan sebelumnya dan telah memiliki pengalaman mengatasi nyeri pada persalinan sebelumnya. Selain faktor paritas, usia juga bisa sebagai salah satu faktor dalam menentukan toleransi terhadap nyeri persalinan, karena usia responden dalam penelitian ini usia yang masih reproduktif, sehingga kondisi fisik ibu lebih kuat, kondisi psikologis pun sudah mampu mengatasi nyeri persalinan. Sejalan dengan penelitian Ayu \& Supliyani (2017) yang menunjukkan bahwa sebagian besar responden dalam usia reproduktif, sehat dan secara fisiologis pada usia tersebut memungkinkan ibu masih kuat menahan nyeri.

\section{Lamanya Persalinan}

Pada penelitian ini lamanya persalinan yang paling terbesar pada teknik rebozo sifting while lying down yaitu selama 154 menit dan yang terendah pada teknik rebozo shake the apples selama 139 menit. Lamanya persalinan pada penelitian ini diambil dari durasi kala I fase aktif sampai kala II dengan hasil kurang dari nilai normal lamanya persalinan tersebut. 
Hal ini dapat di pengaruhi dari faktor usia yang masih reproduktif, paritas multigravida dan fisologis seperti ketebalan porsio serviks, his dan kekuatan ibu dalam meneran selama persalinan. Lamanya persalinan merupakan waktu yang dibutuhkan selama proses persalinan, dimana normal waktu persalinan pada multigravida kala I fase aktif berkisar 6-8 jam atau 360-480 menit.

Berdasarkan penelitian Rusniati et al., (2017) bahwa pada ibu bersalin multigravida dengan lamanya persalinan kala I sebanyak 18 responden $(51,4 \%)$ dengan lamanya persalinan 9 jam. Sedangkan lama persalinan pada kala II sebanyak 29 orang $(82,9 \%)$ dengan lamanya persalinan 61-100 menit.

Perbedaan Rata-Rata Intensitas Nyeri Persalinan Kala I Fase Aktif pada Ibu Multigravida Sebelum dan Sesudah Pemberian Intervensi pada Teknik Rebozo Shake the Apples dan Rebozo Sifting While Lying Down

Berdasarkan hasil analisis dependent sample t-test terlihat nilai signifikan 2-tailed < 0,05, maka terdapat perbedaan signifikan antara pre dan post pada intervensi teknik rebozo shake the apples maupun teknik rebozo sifting while lying down. Rebozo merupakan kain selendang/jarik yang menggunakannya di panggul ibu bersalin, dengan gerakan terkontrol untuk membantu menggerakkan pinggul atau sedikit mengayunkannya dari sisi ke sisi. Gerakan ini yang memberikan tekanan dengan cara goyang atau goncangan di bagian panggul secara terus-menerus selama kontraksi, dimana penekanan tersebut tepatnya diletakkan pada tulang lumbal, sakrum dan koksigis (Lumbosacral) pasien dengan kain rebozo. Tentunya di daerah lumbosacral ini dimana saraf sensorik rahim dan mulut rahim berjalan bersama saraf simpatis rahim memasuki sumsum tulang belakang melalui saraf torakal 10, 11, 12 sampai lumbal 1, impuls nyeri ini dapat diblok dengan memberikan rangsangan pada saraf yang berdiameter besar dengan teknik rebozo shake the apples atau rebozo sifting while lying down, sehingga impuls nyeri berjalan dari uterus sepanjang seratserat saraf $c$-fiber menuju ke subtansia gelatinosa di dalam spinal colum, lalu sel-sel tersebut memproyeksikan pesan nyeri yang berlawanan sepanjang serat-serat saraf a-delta fibers yang menyebabkan gate control akan tertutup dan rangsangan nyeri tidak dapat diteruskan ke korteks serebral, maka persepsi di otak nyeri menjadi berkurang. Mekanisme rebozo inilah yang dapat membantu mengalihkan nyeri persalinan.

Menurut penelitian Iversen et al., (2017) bahwa teknik rebozo shake the apples dan rebozo sifting while lying down juga memberi efek positif pada persalinan, salah satunya meningkatkan rasa kenyamanan selama persalinan. Hal tersebut terbukti bahwa teknik rebozo shake the apples maupun teknik rebozo sifting while lying down sangat berpengaruh terhadap nyeri persalinan.

Perbedaan Rata-Rata Lamanya Persalinan pada Ibu Multigravida dalam Pemberian Intervensi pada Teknik Rebozo Shake the Apples dan Rebozo Sifting While Lying Down

Berdasarkan hasil analisis Dependent Sample T-Test lamanya persalinan terlihat nilai signifikan 2-tailed $>0,05$, maka tidak terdapat perbedaan yang signifikan rata-rata lamanya persalinan antara intervensi teknik rebozo shake the apples dengan teknik rebozo sifting while lying down. Hal ini terjadi karena pengukuran durasi lamanya persalinan hanya dilihat di akhir setelah dilakukan intervensi dari kala I fase aktif sampai bayi lahir, sedangkan sebelum dilakukan intervensi tidak ada pengukuran nilai lamanya persalinan. 
Sehingga dari intervensi teknik rebozo shake the apples dan teknik rebozo sifting while lying down mendapatkan nilai lamanya persalinan perbedaan durasinya sedikit yaitu 154 menit pada rebozo shake the apples dan 139 menit pada teknik rebozo sifting while lying down. Dimana durasi tersebut kurang dari 360 menit pada kala I fase aktif pada multigravida, artinya teknik rebozo ini dapat mempengaruhi lamanya persalinan. Biasanya lama persalinan pada fase aktif idealnya tidak lebih dari 10 jam, sedangkan pada ibu multigravida lama persalinan kala I fase aktif kurang lebih 6-8 jam.

Sedangkan di dalam penelitian Rusniati et al., (2017) lama proses persalinan pada fase aktif 6 jam. Pada kala II pada multigravida lamanya persalinan 1 jam. Hal ini disebabkan adanya penekanan teknik rebozo pada tulang panggul membantu mengendurkan otot-otot di sekitar panggul dan penekanan bagian lumbal akan meningkatkan reseptor oksitosin yang menyebabkan kualitas kontraksi uterus menjadi adekuat, sehingga penurunan presentasi menjadi lebih cepat mempengaruhi percepatan proses persalinan. Selain hal tersebut bisa juga dipengaruhi dari kondisi jalan lahir, karena jalan lahir pada multigravida lebih lunak dibandingkan yang primigravida, hal ini memungkinkan percepatan lamanya persalinan.

Efektifitas Teknik Rebozo Shake the Apples dengan Teknik Rebozo Sifting While Lying Down Terhadap Intensitas Nyeri Persalinan Kala I Fase Aktif pada Ibu Multigravida

Hasil penelitian terbukti bahwa hasil analisis pada asumsi homogenitas antar 4 pengukuran intensitas nyeri persalinan pada intervensi teknik rebozo shake the apples dengan rebozo sifting while lying down didapatkan $p$ value $0,118>0,05$, artinya pada kedua teknik rebozo memiliki varian sama atau homogen. Sehingga dapat disimpulkan dari dua intervensi yang diberikan terdapat perbedaan pengukuran intensitas nyeri persalinan dan lamanya persalinan terhadap teknik rebozo shake the apples dengan teknik rebozo sifting while lying down, meskipun tidak terlalu besar, jadi dari dua kelompok intervensi dikatakan sama-sama efektif dalam mengalihkan nyeri persalinan kala I fase aktif dan lamanya persalinan pada ibu multigravida.

Dapat kita ketahui bahwa pada pengukuran pertama dari teknik rebozo shake the apples dan teknik rebozo sifting while lying down merupakan pengukuran intensitas nyeri persalinan kala I fase aktif sebelum dilakukan intervensi teknik rebozo, sehingga intensitas nyeri persalinan masih berat. Pada teknik rebozo shake the apples konsistensi penurunan nyeri persalinan sangat cepat yaitu pada pengukuran ketiga dan pada pengukuran ke empat sedikit naik, sedangkan pada teknik rebozo sifting while lying down konsistensi penurunan intensitas nyeri persalinan pada pengukuran ke 4 dan sedikit agak melambat dibandingkan teknik rebozo shake the apples. Hal ini kemungkinan terjadi karena penekanan rebozo pada lumbosacral lebih kuat dan efektif pada posisi genu pektoral teknik shake the apples dibandingkan posisi semi fowler teknik rebozo sifting while lying down. Artinya kemungkinan bisa dipengaruhi oleh posisi pasien. Terbukti dari lamanya persalinan pun pada teknik rebozo shake the apples lebih cepat (139 menit) dibandingkan lamanya persalinan teknik rebozo sifting while lying down (154 menit). Namun posisi semi fowler pada penelitian ini kakinya tidak terbuka ke samping, tapi diberi posisi kaki lurus ke depan, selain dari masalah penekanan rebozo, kemungkinan posisi kaki ini lah yang memperlambat proses mengalihkan nyeri dan lamanya persalinan, karena dengan posisi 
tersebut peregangan jalan lahir tidak maksimal dibandingkan posisi kaki yang terbuka kesamping.

Pada teknik rebozo shake the apples dan rebozo sifting while lying down apples secara teknik sangat aman dan lebih rileks bila dilakukan sesuai protokol teknik rebozo, dan secara privasi pakaian pasien tetap lengkap, tirai atau pintu ruangan ditutup, ventilasi ruangan cukup baik dan secara ekonomi pasien tidak mengeluarkan biaya sama sekali dan dari segi waktu juga sangat singkat. Namun mengingat responden pada penelitian ini pada ibu multigravida, selain dari pengaruh teknik rebozo ini, maka kemungkinan bisa juga dipengaruhi adanya faktor yang lain seperti paritas, pengalaman persalinan, dan koping individu dalam menghadapi persalinan. Begitu juga dengan lamanya persalinan, dimana lamanya persalinan dalam penelitian ini kemungkinan dapat dipengaruhi kondisi fisiologis maupun psikologis pasien seperti ketebalan porsio servik, power, his dan rasa cemas pasien.

Sejalan dengan penelitian Iversen et al., (2017) bahwa teknik rebozo shake the apples dan rebozo sifting while lying down juga memberi efek positif pada persalinan, salah satunya meningkatkan rasa kenyamanan selama persalinan. Adapun di dalam penelitian Iversen terdapat teknik rebozo shake the apples dengan teknik rebozo sifting while lying down yang mana diantara dua teknik ini sama-sama memberi kenyamanan pada pasien. Dimana teknik rebozo ini secara anatomis dapat menekan area lumbal sampai koksigis dengan kain lurik atau rebozo, dengan stimulus teknik rebozo ini dapat mengakibatkan peregangan pada otot panggul dan mengeluarkan endorphin dalam darah, dan membantu mengatur kontraksi serta mengembalikan keseimbangan pada proses persalinan.

\section{SIMPULAN}

Teknik rebozo shake the apples dan rebozo sifting while lying down dapat mengalihkan nyeri persalinan kala I fase aktif dan mempercepat proses persalinan pada ibu multigravida.

\section{SARAN}

Saran yang diharapkan pada penelitian ini dapat digunakan sebagai salah satu referensi evidence based practice dalam ilmu keperawatan, dapat diterapkan dipelayanan maternitas sebagai tindakan alternatif dari non farmakologis pada persalinan kala I fase aktif dan pengembangan riset selanjutnya.

\section{DAFTAR PUSTAKA}

Ayu, N. G., \& Supliyani, E. (2017). Karakteristik Ibu Bersalin Kaitannya dengan Intensitas Nyeri Persalinan Kala 1 di Kota Bogor. Jurnal Kebidanan Malahayati, 3(4), 204210.

http://www.ejurnalmalahayati.ac.id/index.php/kebidanan/article/viewFile/629/563

Iversen, M. L., Midtgaard, J., Ekelin, M., \& Hegaard, H. K. (2017). Danish Women's Experiences of the Rebozo Technique during Labour: A Qualitative Explorative Study. Sexual \& Reproductive Healthcare: Official Journal of the Swedish Association of Midwives, $11, \quad 79-85$. https://doi.org/https://doi.org/10.1016/j.srhc.2016.10.005 
Maryuni, M. (2020). Hubungan Karakteristik Ibu Bersalin dengan Nyeri Persalinan. Journal of Health Science and Physiotherapy, 2(1), 116-122. https://jurnal.stikessitihajar.ac.id/index.php/jhsp/article/view/42

Purnama, Y., \& Dewiani, K. (2019). Pengaruh Posisi Tegak terhadap Intensitas Nyeri Persalinan pada Primipara di Bidan Praktik Mandiri (Bpm) Kota Bengkulu. Journal Of Midwifery, 7(1), 52-59. https://doi.org/10.37676/jm.v7i1.739

Puspitasari, I., \& Astuti, D. (2017). Teknik Massage Punggung untuk Mengurangi Nyeri Persalinan Kala I. Jurnal Ilmu Keperawatan Dan Kebidanan, 8(2), 100. https://doi.org/10.26751/jikk.v8i2.289

Rusniati, R., Halimatussakdiah, H., \& Halimatussakdiah, H. (2017). Tindakan Keperawatan Post Partum Normal dan Adaptasi Fisiologi pada Ibu Postpartum di Rumah Sakit Aceh. Jurnal Ilmiah Mahasiswa Fakultas Keperawatan, 2(4), 1-5. http://jim.unsyiah.ac.id/FKep/article/view/4533

Supliyani, E. (2017). Pengaruh Mesaage Punggung terhadap Intensitas Nyeri Persalinan Kala I di Kota Bogor. Bidan Midwife Journal, 3(1), 22-29. http://repository.poltekkesbdg.info/items/show/2090

Wulandari, D. A., \& Putri, A. N. T. (2018). Aplikasi Tekhnik Effleurage sebagai Penatalaksanaan Nyeri Persalinan Ibu. Jurnal Urecol, 538-543. http://repository.urecol.org/index.php/proceeding/article/view/233/229 